Original Article

\title{
A comprehensive overview of miRNA targeting drought stress resistance in plants
}

\author{
Uma visão geral abrangente do miRNA visando a resistência ao estresse hídrico em \\ plantas
}

\section{S. M. S. Shaha* (1) and F. Ullah ${ }^{\mathrm{b}}$ (1)}

${ }^{a}$ Chinese Academy of Agricultural Sciences, Institute of Crop Science, National Engineering Laboratory for Crop Molecular Breeding, Beijing, China

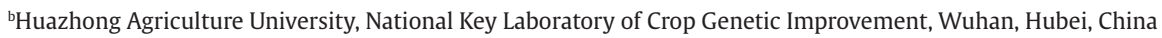

\begin{abstract}
MicroRNAs (miRNAs) are essential nonprotein-coding genes. In a range of organisms, miRNAs has been reported to play an essential role in regulating gene expressions at post-transcriptional level. They participate in most of the stress responsive processes in plants. Drought is an ultimate abiotic stress that affects the crop production. Therefore understanding drought stress responses are essential to improve the production of agricultural crops. Throughout evolution, plants have developed their own defense systems to cope with the adversities of environmental stresses. Among defensive mechanisms include the regulations of gene expression by miRNAs. Drought stress regulates the expression of some of the functionally conserved miRNAs in different plants. The given properties of miRNAs provide an insight to genetic alterations and enhancing drought resistance in cereal crops. The current review gives a summary to regulatory mechanisms in plants as well as miRNAs response to drought stresses in cereal crops. Some possible approaches and guidelines for the exploitation of drought stress miRNA responses to improve cereal crops are also described.
\end{abstract}

Keywords: miRNA, drought, crop, gene regulation, gene expression, cereal crops.

\begin{abstract}
Resumo
MicroRNAs (miRNAs) são genes essenciais não codificadores de proteínas. Em uma variedade de organismos, foi relatado que miRNAs desempenham papel essencial na regulação da expressão gênica em nível pós-transcricional. Eles participam da maioria dos processos responsivos ao estresse nas plantas. A seca é um estresse abiótico final que afeta a produção agrícola. Portanto, compreender as respostas ao estresse da seca é essencial para melhorar a produção de safras agrícolas. Ao longo da evolução, as plantas desenvolveram seus próprios sistemas de defesa para lidar com as adversidades do estresse ambiental. Entre os mecanismos de defesa está a regulação da expressão gênica por miRNAs. O estresse hídrico regula a expressão de alguns dos miRNAs funcionalmente conservados em diferentes plantas. As propriedades dadas dos miRNAs fornecem uma visão das alterações genéticas e aumentam a resistência à seca nas safras de cereais. A revisão atual apresenta um resumo dos mecanismos regulatórios nas plantas, bem como a resposta dos miRNAs ao estresse hídrico nas plantações de cereais. Algumas abordagens e diretrizes possíveis para a exploração das respostas do miRNA ao estresse da seca para melhorar as safras de cereais também são descritas.
\end{abstract}

Palavras-chave: miRNA, seca, cultura, regulação gênica, expressão gênica, cultura de cereais.

\section{Introduction}

Drought is an utmost significant abiotic stress that affects the growth, development and production of several plants (Ceccarelli and Grando, 1997). Some regions with inadequate water are more inclined to drought due to irregular changes in weather conditions. Moreover, lack of water resources resulting from increasing human needs and growing harsh climatic conditions amplify the effects of drought several folds (Rosegrant and Cline, 2003). Drought tolerance is a complex trait aided by morphological, physiological and biochemical adaptations (Zhu, 2002; Shinozaki et al., 2003; Bohnert et al., 2006). These adaptations to drought stress are at least partially dependent on changes in gene expression. Regulation of gene expression at the transcriptional level is crucial for

*e-mail: smsadiqshah@hotmail.com

Received: August 25, 2020 - Accepted: March 06, 2021 
plant drought resistance by altering the expression of still other downstream genes (Singh et al., 2002). It has been shown that altering the expression of transcription factors, including CBFs/DREBs, NACs and NF-YAs, could alter stress resistance and plant hormone action by downstream regulation of the target genes (Kasuga et al., 1999; Hu et al., 2006; Li et al., 2008).

Recently, many researchers have focused on microRNAs (miRNAs) because of their significant roles in gene regulation mechanisms through heterochromatin modification, post-transcriptional gene silencing or translational inhibition (Carrington and Ambros, 2003; Bartel, 2004; Vaucheret, 2006). miRNAs are processed by the ribonuclease III-like enzyme Dicer-like (DCL) 1 or DCL4 from single-stranded RNA precursors that are capable of forming hairpin structures (Kurihara and Watanabe, 2004; Rajagopalan et al., 2006). Plant miRNAs regulate several physiological processes including auxin signaling, leaf morphogenesis, flowering time and embryo development (Carrington and Ambros, 2003; Bartel, 2004; Allen et al., 2005). Increased researches support the vital roles of miRNAs in orchestrating important agronomic traits in crops (Tang and Chu, 2017). Recent studies have also reported the key roles of plant miRNAs to drought stress adaptation (Li et al., 2008; Du et al., 2017; Ferdous et al., 2017a), which made miRNAs as the promising candidates for molecular breeding of crops with increased drought resistance. The current review highlights the recent advances of miRNA-mediated adaptation to drought-stress in plants. Furthermore, it also focuses on their potential roles in molecular breeding of crops for increased drought resistance.

\section{2. miRNA Responses to Drought Conditions}

A number of drought-responsive miRNAs have been identified in Arabidopsis, common bean, cowpea, rice, tobacco and soybean using global expression profiling analysis (Sunkar and Zhu, 2004; Arenas-Huertero et al., 2009; Zhou et al., 2010; Barrera-Figueroa et al., 2011; Frazier et al., 2011; Kulcheski et al., 2011). In Arabidopsis, drought stress upregulated miR156, miR159, miR167, miR168, miR171, miR172, miR319, miR393, miR394a, miR395c, miR395e, miR396 and miR397 whereas decreased the expression level of miR161, miR168a, miR168b, miR169, miR171a and miR319c (Sunkar and Zhu, 2004; Liu et al., 2008).

In several cases, it had been revealed that the responses of miRNAs to drought stress depended on species. For example, miR1510 was decreased in Medicago truncatula while increased in Glycine max by drought treatment (Mantri et al., 2013); In contrast to the down-regulation in rice and maize by drought stress (Wei et al., 2009; Zhou et al., 2010), miR156 abundance is upregulated in Arabidopsis, barley, peach and wild emmer wheat (Sunkar and Zhu, 2004; Kantar et al., 2010, 2011; Eldem et al., 2012). Being one of the major miRNA families in plants, miR169 also revealed differential expression to drought conditions in many species. Overexpressing miR169a in
Arabidopsis, exhibited enhanced transpiration and drought sensitivity as compared to wild type (WT) plants (Li et al., 2008). Nevertheless, transgenic tomato over-expressing Sly-miR169c exhibited decreased transpiration rate, reduced stomatal opening, decreased leaf water loss but enhanced drought resistance (Zhang et al., 2011).

The members of miRNA family have been assumed to have redundant functions; nevertheless, closely related miRNAs that were projected to target the same genes differentially responded to osmotic stress. In rice, members of MIR319 family were both up- and down-regulated (Zhou et al., 2010). Using soil grown Arabidopsis plants, it had been reported that only MIR169a and MIR169c were substantially down-regulated by drought stress; Co-expression of miR169 and NFYA5 (nuclear transcription factor Y in Arabidopsis thaliana) proposed that MIR169a was more proficient as compared to MIR169c at limiting the level of NFYA5 mRNA (Li et al., 2008). In contrast; MIR169j, MIR169l, and MIR169m expression significantly increased when Arabidopsis seedlings were exposed to dehydration shock for 3 hours. Furthermore, it has also been reported that MIR169j and MIR169l mainly affected NFYA5 expression at the translational level and miRNA/miRNA* complementarity as the determinant triggering differences in the NFYA5 regulation pattern by MIR169a and MIR169l (Du et al., 2017). It has also been reported that the miR169 family in Arabidopsis is highly conserved in Populus trichocarpa and Oryza sativa. Therefore it is assumed that the regulatory modes of miR169 by water stress may also be related to other plants.

\section{3. miRNAs Target Drought-Responsive Genes}

miRNA-target regulatory module is important for plant adaption to drought stresses. Some targets are regulatory proteins. Nuclear factor $Y(N F-Y)$ is a universal transcription factor that contains NF-YA (also known as CBF-B or HAP2), NF-YB (CBF-A or HAP3) and NF-YC (CBF-C or HAP5). NF-Y recognizes CCAAT box (cis-element) comprising of $\sim 25 \%$ of eukaryotic gene promoters. NF-YAs were targeted by miR169 as mentioned above. In Arabidopsis, NFYA5 knockout plants were highly sensitive to drought stress as compare to WT plants. However, overexpression of NFYA5 Arabidopsis plants showed significant drought stress tolerance (Li et al., 2008). Interestingly, microarray study revealed that NFYA5 is essential for many drought stress-responsive gene expressions, including subunit of cytochrome $b 6-f$ complex, GST, oxidoreductase family protein and peroxidases (Li et al., 2008). In P. trichocarpa, the expression of miR164/ miR160 and their targets, $A R F$ and NAC domain TFs, was down- and up-regulated respectively under drought conditions (Shuai et al., 2013). Overexpression of the given TFs changed the sensitivity to exogenous Abscisic acid (ABA) in Arabidopsis (Liu et al., 2007) and enhanced drought resistance in rice (Hu et al., 2006).

Drought stress improved ABA contents in maize seedlings, which led to the accumulation of reactive 
oxygen species (ROS), targeting the up-regulation of mitogen-activated protein kinase (MAPK) to enhance the expression of corresponding antioxidant genes and proteins (Wei et al., 2009). Down-regulation of miR528 and miR168 in maize seedlings under drought stress was accompanied by the accumulation of their corresponding targets, MAPK (Mitogen Activated Protein Kinase) and POD (Peroxidase) (Wei et al., 2009), further suggesting that miRNAs benefit antioxidant defense of plant cells caused by drought stress.

\section{Drought-Responsive miRNAs and Plant Hormones}

ABA accumulation is required for some drought stressinduced up-regulation of gene expression (Zhu, 2002). In Arabidopsis, ABA treatment reduced the level of miR169 to approximately $16 \%$ of the control level; however, miR169 expression in the ABA-deficient mutant (aba2-1) and ABA-insensitive mutant (abi1-1) was not significantly affected by drought (Li et al., 2008), indicating that miR169 was down-regulated by drought stress through an ABA-dependent pathway. In germinating Arabidopsis thaliana seeds, ABA induced the miR159 abundance in an ABI3-dependent pattern (Reyes and Chua, 2007). The null mutants of miR159 targets, MYB33 and MYB101, as well as plants overexpressing miR159a showed hyposensitivity to ABA. In contrast, overexpressing cleavage-resistant forms of MYB101 or MYB33 were found to be ABA hypersensitive (Reyes and Chua, 2007). It have been reported that miR396 and miR168 was upregulated by drought stress (Liu et al., 2008). Using the PlantCARE program (http://bioinformatics. psb.ugent.be/webtools/plantcare), ABRE (ABA responsive element) sequences could be found in the promoter region of miR159a, miR167c, miR168, miR393b, miR396b and miR408. Therefore it is suggested that these miRNAs could be directly affected by ABA treatment (Liu et al., 2008).

Plants inhibit the lateral root growth to allow the redirection of resources for deeper roots production during drought stresses. The lateral root growth is inhibited by ABA formation under drought conditions (Xiong et al., 2006). An elevated level of miR393 suppressed the lateral root growth of an ABA hypersensitive mutant through direct cleavage of two auxin receptors, TIR1 and AFB2 (Chen et al., 2012). The lateral root growth of Arabidopsis seedlings expressing miR393-resistant TIR1 or AFB2 was no longer inhibited by ABA or osmotic stress (Chen et al., 2012). Furthermore, TGA element and AuxRR core could be found in the promoter region of miR156a, miR159a, miR167d, miR168, miR171b, miR319b, miR319c, miR393a, miR393b, miR393c, miR397 and miR408 (Liu et al., 2008). These results suggested that miRNA-mediated auxin signaling modulates plant adaptation to drought stress.

Leaf senescence is a basic mechanism to avoided drought by reducing transpiration and canopy size. In higher plants, ethylene generation is trigger by drought stress, which accelerates leaves senescence (Apelbaum and Yang, 1981; McKeon et al., 1982). The role of miR164 in leaf senescence has been described in detail in Arabidopsis. The expression level of miR164 gradually decreases with aging through negative regulation by EIN2 (ETHYLENE INSENSITIVE 2), which led to the concurrent upregulation of ORE1 (oresara1-1) (Kim et al., 2009). An enhancement in the leaf longevity has been observed by the overexpression of miR164 and/or absence of its target ORE1 (Kim et al., 2009). EIN3 is a key transcription factor in ethylene signaling. Constitutive or temporary activation of EIN3 is sufficient to accelerate leaf senescence in Arabidopsis; In contrast, ein3 loss-of-function mutant postponed dark-induced leaf senescence (Li et al., 2013). EIN3 could bind the promoters of miR164, and EIN3-induced early-senescence phenotypes were repressed in 35S::MIR164 transgenic plants (Li et al., 2013). It gives an idea to link the abovementioned pathway to the plant adaptation to drought stress.

\section{5. miRNAs as Candidates for Breeding Drought- Resistance Crops}

A systematic analysis of MIRNA genes in the close relatives, Arabidopsis thaliana and Arabidopsis lyrata, indicated that at least $13 \%$ of MIRNA genes in each species are unique (Fahlgren et al., 2010). A polymorphism survey of 94 small RNA loci in domesticated rice demonstrated that many substitutions or insertions/deletions existed at small RNA loci and several small RNA loci showed significant signals for positive selection and/or potential domestication selection (Wang et al., 2010). By analysis of expression patterns and single-nucleotide polymorphism (SNP)-based association studies in 435 unrelated individuals of Populus tomentosa, it was observed that allelic interactions among Pto-MIR475b and its four target genes potentially affect growth and wood properties in Populus (Xiao et al., 2017) [43]. These results suggested that miRNAs could be used as molecular markers for improving agronomic traits of crops, including drought resistance.

Altering miRNA levels could affect the drought resistance of crops. miR408 targets copper related genes and miR408 overexpression increased drought tolerance in chickpea (Hajyzadeh et al., 2015); OsmiR393-overexpressing rice showed increased tillers, early flowering and reduced tolerance to salt and drought stresses (Xia et al., 2012); Transgenic creeping bentgrass overexpressing OsamiR319a exhibited enhanced drought tolerance associated with increased leaf wax content (Zhou M et al., 2013). Of course, overexpression of miRNAs could not always obtain beneficial traits. The growth, agricultural water use efficiency (WUE) and productivity (WP), time to anthesis and grain weight of transgenic barley plants expressing CaMV-35S::Ath-miR827 were negatively affected in both well-watered and drought conditions compared with WT (Ferdous et al., 2017b). In contrast, transgenic plants over-expressing Zm-Rab17::Hv-miR827 showed improved WUEwp (Ferdous et al., 2017b), suggesting that the nature of promoter is important for the phenotypic performance of transgenic crops. A summary of functionally validated miRNAs related to drought resistance in plants has been given in Table 1. 
Table 1. Summary of functionally validated miRNAs related to drought resistance in plants.

\begin{tabular}{|c|c|c|c|c|}
\hline miRNAs & Plants & Method & Phenotype & Ref \\
\hline miR164b & Arabidopsis & overexpression & drought tolerance & (Wang et al., 2016) \\
\hline $\operatorname{miR} 165 / 166$ & Arabidopsis & knock-down & $\begin{array}{l}\text { cold and drought } \\
\text { tolerance }\end{array}$ & (Yan et al., 2016) \\
\hline $\operatorname{miR} 168$ & Arabidopsis & overexpression & $\begin{array}{l}\text { ABA hypersensitivity } \\
\text { and drought tolerance }\end{array}$ & (Li et al., 2012) \\
\hline miR169a & Arabidopsis & overexpression & drought sensitivity & (Li et al., 2008) \\
\hline miR169i/l & Arabidopsis & overexpression & drought tolerance & (Du et al., 2017) \\
\hline $\operatorname{miR} 169 c$ & Tomato & overexpression & drought tolerance & (Zhang et al., 2011) \\
\hline $\operatorname{miR} 172$ & Arabidopsis & overexpression & drought sensitivity & (Han et al., 2013) \\
\hline $\operatorname{miR} 172 \mathrm{c}$ & soybean & overexpression & drought tolerance & (Li et al., 2016) \\
\hline miR319a & $\begin{array}{l}\text { creeping bentgrass, } \\
\text { rice }\end{array}$ & overexpression & drought tolerance & $\begin{array}{l}\text { (Yang et al., 2013; } \\
\text { Zhou et al., 2013) }\end{array}$ \\
\hline miR393 & rice & overexpression & drought sensitivity & (Xia et al., 2012) \\
\hline miR394a & Arabidopsis, soybean & overexpression & drought tolerance & $\begin{array}{l}\text { (Ni et al., 2012; } \\
\text { Song et al., 2013) }\end{array}$ \\
\hline miR396a & tobacco & overexpression & drought tolerance & (Chen et al., 2015) \\
\hline miR399f & Arabidopsis & overexpression & drought sensitivity & (Baek et al., 2016) \\
\hline $\operatorname{miR} 408$ & Arabidopsis, chickpea & overexpression & $\begin{array}{l}\text { drought sensitivity, } \\
\text { drought tolerance }\end{array}$ & $\begin{array}{l}\text { (Hajyzadeh et al., } \\
\text { 2015; Ma et al., 2015) }\end{array}$ \\
\hline $\operatorname{miR} 2118$ & tobacco & overexpression & drought tolerance & (Wu et al., 2015) \\
\hline
\end{tabular}

\section{Conclusion}

The agriculture yield is prone to harsh environmental stresses including biotic and abiotic stresses. Drought being one of the major threats has devastating effects on the crop yield and production across the globe. Drought stress a complex trait that is controlled by several genes regulatory networks mainly constitutes miRNAs. A little is known about the actual mechanism involved to confer stress resistance through miRNAs by targeting regulatory networks. It might be attributed to the regulation of multiple genes by miRNAs under stress conditions. Although the targets of several miRNAs are still unclear but their roles for conferring drought resistance to plants has been reported in many studies. Therefore, it is a major challenge to study and identify targets for miRNAs and their major functions. The given piece of information will aid the research aimed to identify miRNAs as well as their targets contributing to drought stress resistance. Another important consideration will be the characterization of cis-regulatory elements in miRNAs genes and their TFs towards drought stress responses. The given article will also provide an insight to recognize the mode of action for future research aiming abiotic stress especially drought resistance.

\section{References}

ALLEN, E., XIE, Z., GUSTAFSON, A.M. and CARRINGTON, J.C., 2005. microRNA-directed phasing during trans-acting siRNA biogenesis in plants. Cell, vol. 121, no. 2, pp. 207-221. http:// dx.doi.org/10.1016/j.cell.2005.04.004. PMid:15851028.
APELBAUM, A. and YANG, S.F., 1981. Biosynthesis of stress ethylene induced by water deficit. Plant Physiology, vol. 68, no. 3, pp. 594-596. http://dx.doi.org/10.1104/pp.68.3.594. PMid:16661963.

ARENAS-HUERTERO, C., PÉREZ, B., RABANAL, F., BLANCO-MELO, D., ROSA, C., ESTRADA-NAVARRETE, G., SANCHEZ, F., COVARRUBIAS, A.A. and REYES, J.L., 2009. Conserved and novel miRNAs in the legume Phaseolus vulgaris in response to stress. Plant Molecular Biology, vol. 70, no. 4, pp. 385-401. http://dx.doi.org/10.1007/ s11103-009-9480-3. PMid:19353277.

BAEK, D., CHUN, H.J., KANG, S., SHIN, G., PARK, S.J., HONG, H., KIM, C., KIM, D.H., LEE, S.Y., KIM, M.C. and YUN, D.J., 2016. A role for Arabidopsis miR399f in salt, drought, and ABA signaling. Molecules and Cells, vol. 39, no. 2, pp. 111-118. http://dx.doi. org/10.14348/molcells.2016.2188. PMid:26674968.

BARRERA-FIGUEROA, B.E., GAO, L., DIOP, N.N., WU, Z., EHLERS, J.D., ROBERTS, P.A., CLOSE, T.J., ZHU, J.-K. and LIU, R., 2011. Identification and comparative analysis of drought-associated microRNAs in two cowpea genotypes. BMC Plant Biology, vol. 11, no. 1, pp. 127. http://dx.doi.org/10.1186/1471-2229-11-127. PMid:21923928.

BARTEL D.P., 2004. MicroRNAs: genomics, biogenesis, mechanism, and function. Cell, vol. 116, no. 2, pp. 281-297.

BOHNERT, H.J., GONG, Q., LI, P. and MA, S., 2006. Unraveling abiotic stress tolerance mechanisms-getting genomics going. Current Opinion in Plant Biology, vol. 9, no. 2, pp. 180-188. http://dx.doi. org/10.1016/j.pbi.2006.01.003. PMid:16458043.

CARRINGTON, J.C. and AMBROS, V., 2003. Role of microRNAs in plant and animal development. Science, vol. 301, no. 5631, pp. 336-338. http://dx.doi.org/10.1126/science.1085242. PMid:12869753.

CECCARELLI, S. and GRANDO, S., 1997. Drought as a challenge for the plant breeder. In: E. Belhassen, ed. Drought tolerance in higher plants: genetical, physiological and molecular biological analysis. Dordrecht: Springer Netherlands, pp. 71-77. 
CHEN, H., LI, Z. and XIONG, L., 2012. A plant microRNA regulates the adaptation of roots to drought stress. FEBS Letters, vol. 586, no. 12, pp. 1742-1747. http://dx.doi.org/10.1016/j.febslet.2012.05.013. PMid:22613571.

CHEN, L., LUAN, Y. and ZHAI, J., 2015. Sp-miR396a-5p acts as a stress-responsive genes regulator by conferring tolerance to abiotic stresses and susceptibility to Phytophthora nicotianae infection in transgenic tobacco. Plant Cell Reports, vol. 34, no. 12 , pp. 2013-2025. http://dx.doi.org/10.1007/s00299-015-1847-0. PMid:26242449.

DU, Q., ZHAO, M., GAO, W., SUN, S. and LI, W.X., 2017. microRNA/ microRNA complementarity is important for the regulation pattern of NFYA5 by miR169 under dehydration shock in Arabidopsis. The Plant Journal, vol. 91, no. 1, pp. 22-33. http:// dx.doi.org/10.1111/tpj.13540. PMid:28332758.

ELDEM, V., AKÇAY, U.Ç., OZHUNER, E., BAKIR, Y., URANBEY, S. and UNVER, T., 2012. Genome-wide identification of miRNAs responsive to drought in peach (Prunus persica) by highthroughput deep sequencing. PLoS One, vol. 7, no. 12, pp. e50298. http://dx.doi.org/10.1371/journal.pone.0050298. PMid:23227166.

FAHLGREN, N., JOGDEO, S., KASSCHAU, K.D., SULLIVAN, C.M., CHAPMAN, E.J., LAUBINGER, S., SMITH, L.M., DASENKO, M., GIVAN, S.A., WEIGEL, D. and CARRINGTON, J.C., 2010. MicroRNA gene evolution in Arabidopsis lyrata and Arabidopsis thaliana. The Plant Cell, vol. 22, no. 4, pp. 1074-1089. http://dx.doi. org/10.1105/tpc.110.073999. PMid:20407027.

FERDOUS, J., SANCHEZ-FERRERO, J.C., LANGRIDGE, P., MILNE, L., CHOWDHURY, J., BRIEN, C. and TRICKER, P.J., 2017a. Differential expression of microRNAs and potential targets under drought stress in barley. Plant, Cell \& Environment, vol. 40, no. 1, pp. 11-24. http://dx.doi.org/10.1111/pce.12764. PMid:27155357.

FERDOUS, J., WHITFORD, R., NGUYEN, M., BRIEN, C., LANGRIDGE, P. and TRICKER, P.J., 2017b. Drought-inducible expression of Hv-miR827 enhances drought tolerance in transgenic barley. Functional E Integrative Genomics, vol. 17, no. 2-3, pp. 279-292. http://dx.doi.org/10.1007/s10142-016-0526-8. PMid:27730426.

FRAZIER, T.P., SUN, G., BURKLEW, C.E. and ZHANG, B., 2011. Salt and drought stresses induce the aberrant expression of microRNA genes in tobacco. Molecular Biotechnology, vol. 49, no. 2, pp. 159-165. http://dx.doi.org/10.1007/s12033-011-9387-5. PMid:21359858.

HAJYZADEH, M., TURKTAS, M., KHAWAR, K.M. and UNVER, T., 2015. miR408 overexpression causes increased drought tolerance in chickpea. Gene, vol. 555, no. 2, pp. 186-193. http://dx.doi org/10.1016/j.gene.2014.11.002. PMid:25445265.

HAN, Y., ZHANG, X., WANG, W., WANG, Y. and MING, F., 2013. The suppression of WRKY44 by GIGANTEA-miR172 pathway is involved in drought response of Arabidopsis thaliana. PLoS One, vol. 8, no. 11, pp. e73541. http://dx.doi.org/10.1371/journal. pone.0073541. PMid:24223111.

HU, H., DAI, M., YAO, J., XIAO, B., LI, X., ZHANG, Q. and XIONG, L., 2006. Overexpressing a NAM, ATAF, and CUC (NAC) transcription factor enhances drought resistance and salt tolerance in rice. Proceedings of the National Academy of Sciences of the United States of America, vol. 103, no. 35, pp. 12987-12992. http:// dx.doi.org/10.1073/pnas.0604882103. PMid:16924117.

KANTAR, M., LUCAS, S.J. and BUDAK, H., 2011. miRNA expression patterns of Triticum dicoccoides in response to shock drought stress. Planta, vol. 233, no. 3, pp. 471-484. http://dx.doi. org/10.1007/s00425-010-1309-4. PMid:21069383.

KANTAR, M., UNVER, T. and BUDAK, H., 2010. Regulation of barley miRNAs upon dehydration stress correlated with target gene expression. Functional \& Integrative Genomics, vol. 10, no. 4, pp. 493-507. http://dx.doi.org/10.1007/s10142-010-0181-4. PMid:20676715.

KASUGA, M., LIU, Q., MIURA, S., YAMAGUCHI-SHINOZAKI, K. and SHINOZAKI, K., 1999. Improving plant drought, salt, and freezing tolerance by gene transfer of a single stress-inducible transcription factor. Nature Biotechnology, vol. 17, no. 3, pp. 287-291. http://dx.doi.org/10.1038/7036. PMid:10096298.

KIM, J.H., WOO, H.R., KIM, J., LIM, P.O., LEE, I.C., CHOI, S.H., HWANG, D. and NAM, H.G., 2009. Trifurcate feed-forward regulation of age-dependent cell death involving miR164 in Arabidopsis. Science, vol. 323, no. 5917, pp. 1053-1057. http://dx.doi. org/10.1126/science.1166386. PMid:19229035.

KULCHESKI, F.R., DE OLIVEIRA, L.F., MOLINA, L.G., ALMERÃO, M.P., RODRIGUES, F.A., MARCOLINO, J., BARBOSA, J.F., STOLFMOREIRA, R., NEPOMUCENO, A.L., MARCELINO-GUIMARÃES, F.C., ABDELNOOR, R.V., NASCIMENTO, L.C., CARAZZOLLE, M.F., PEREIRA, G.A. and MARGIS, R., 2011. Identification of novel soybean microRNAs involved in abiotic and biotic stresses. BMC Genomics, vol.12, no. 1, pp. 307. http://dx.doi.org/10.1186/14712164-12-307. PMid:21663675.

KURIHARA, Y. and WATANABE, Y., 2004. Arabidopsis micro-RNA biogenesis through Dicer-like 1 protein functions. Proceedings of the National Academy of Sciences of the United States of America, vol. 101, no. 34, pp. 12753-12758. http://dx.doi.org/10.1073/ pnas.0403115101. PMid:15314213.

LI, W., CUI, X., MENG, Z., HUANG, X., XIE, Q., WU, H., JIN, H., ZHANG, D. and LIANG, W., 2012. Transcriptional regulation of Arabidopsis MIR168a and argonaute1 homeostasis in abscisic acid and abiotic stress responses. Plant Physiology, vol. 158, no. 3, pp. 1279-1292. http://dx.doi.org/10.1104/pp.111.188789. PMid:22247272.

LI, W., OONO, Y., ZHU, J., HE, X., WU, J., IIDA, K., LU, X., CUI, X., JIN, H. and ZHU, J., 2008. The Arabidopsis NFYA5 transcription factor is regulated transcriptionally and posttranscriptionally to promote drought resistance. The Plant Cell, vol. 20, no. 8, pp. 2238-2251. http://dx.doi.org/10.1105/tpc.108.059444. PMid:18682547.

LI, W., WANG, T., ZHANG, Y. and LI, Y., 2016. Overexpression of soybean miR172c confers tolerance to water deficit and salt stress, but increases ABA sensitivity in transgenic Arabidopsis thaliana. Journal of Experimental Botany, vol. 67, no. 1, pp. 175194. http://dx.doi.org/10.1093/jxb/erv450. PMid:26466661.

LI, Z., PENG, J., WEN, X. and GUO, H., 2013. Ethylene-insensitive3 is a senescence-associated gene that accelerates age-dependent leaf senescence by directly repressing miR164 transcription in Arabidopsis. The Plant Cell, vol. 25, no. 9, pp. 3311-3328. http:// dx.doi.org/10.1105/tpc.113.113340. PMid:24064769.

LIU, H., TIAN, X., LI, Y., WU, C. and ZHENG, C., 2008. Microarray-based analysis of stress-regulated microRNAs in Arabidopsis thaliana. RNA, vol. 14, no. 5, pp. 836-843. http://dx.doi.org/10.1261/ rna.895308. PMid:18356539.

LIU, P.P., MONTGOMERY, T.A., FAHLGREN, N., KASSCHAU, K.D., NONOGAKI, H. and CARRINGTON, J.C., 2007. Repression of AUXIN RESPONSE FACTOR10 by microRNA160 is critical for seed germination and post-germination stages. The Plant Journal, vol. 52, no. 1, pp. 133-146. http://dx.doi.org/10.1111/j.1365313X.2007.03218.x. PMid:17672844.

MA, C., BURD, S. and LERS, A., 2015. miR408 is involved in abiotic stress responses in Arabidopsis. The Plant Journal, vol. 84, no. 1, pp. 169-187. http://dx.doi.org/10.1111/tpj.12999. PMid:26312768.

MANTRI, N., BASKER, N., FORD, R., PANG, E. and PARDESHI, V., 2013. The role of micro-ribonucleic acids in legumes with a focus on abiotic stress response. The Plant Genome, 
vol. 6, no. 3, pp. 2013.05.0013. http://dx.doi.org/10.3835/ plantgenome2013.05.0013.

MCKEON, T.A., HOFFMAN, N.E. and YANG, S.F., 1982. The effect of plant-hormone pretreatments on ethylene production and synthesis of 1-aminocyclopropane-1-carboxylic acid in water-stressed wheat leaves. Planta, vol. 155, no. 5, pp. 437 443. http://dx.doi.org/10.1007/BF00394473. PMid:24271976.

NI, Z., HU, Z., JIANG, Q. and ZHANG, H., 2012. Overexpression of gma-MIR394a confers tolerance to drought in transgenic Arabidopsis thaliana. Biochemical and Biophysical Research Communications, vol. 427, no. 2, pp. 330-335. http://dx.doi. org/10.1016/j.bbrc.2012.09.055. PMid:23000164.

RAJAGOPALAN, R., VAUCHERET, H., TREJO, J. and BARTEL, D.P., 2006. A diverse and evolutionarily fluid set of microRNAs in Arabidopsis thaliana. Genes \& Development, vol. 20, no. 24, pp. 3407-3425. http://dx.doi.org/10.1101/gad.1476406. PMid:17182867.

REYES, J.L. and CHUA, N.H., 2007. ABA induction of miR159 controls transcript levels of two MYB factors during Arabidopsis seed germination. The Plant Journal, vol. 49, no. 4, pp. 592-606. http:// dx.doi.org/10.1111/j.1365-313X.2006.02980.x. PMid:17217461.

ROSEGRANT, M.W. and CLINE, S.A., 2003. Global food security: challenges and policies. Science, vol. 302, no. 5652, pp. 1917-1919. http://dx.doi.org/10.1126/science.1092958. PMid:14671289.

SHINOZAKI, K., YAMAGUCHI-SHINOZAKI, K. and SEKI, M., 2003. Regulatory network of gene expression in the drought and cold stress responses. Current Opinion in Plant Biology, vol. 6, no. 5 , pp. 410-417. http://dx.doi.org/10.1016/S1369-5266(03)00092-X. PMid:12972040.

SHUAI, P., LIANG, D., ZHANG, Z., YIN, W. and XIA, X., 2013. Identification of drought-responsive and novel Populus trichocarpa microRNAs by high-throughput sequencing and their targets using degradome analysis. BMC Genomics, vol. 14, no. 1, pp. 233. http://dx.doi.org/10.1186/1471-2164-14-233. PMid:23570526.

SINGH, K.B., FOLEY, R.C. and OÑATE-SÁNCHEZ, L., 2002. Transcription factors in plant defense and stress responses. Current Opinion in Plant Biology, vol. 5, no. 5, pp. 430-436. http://dx.doi.org/10.1016/ S1369-5266(02)00289-3. PMid:12183182.

SONG, J.B., GAO, S., SUN, D., LI, H., SHU, X.X. and YANG, Z.M., 2013. miR394 and LCR are involved in Arabidopsis salt and drought stress responses in an abscisic acid-dependent manner. BMC Plant Biology, vol. 13, no. 1, pp. 210. http://dx.doi. org/10.1186/1471-2229-13-210. PMid:24330668.

SUNKAR, R. and ZHU, J.-K., 2004. Novel and stress-regulated microRNAs and other small RNAs from Arabidopsis. The Plant Cell, vol. 16, no. 8, pp. 2001-2019. http://dx.doi.org/10.1105/ tpc.104.022830. PMid:15258262.

TANG J. and CHU C., 2017. MicroRNAs in crop improvement: fine-tuners for complex traits. Nature Plants, vol. 3, pp. 17077.

VAUCHERET, H., 2006. Post-transcriptional small RNA pathways in plants: mechanisms and regulations. Genes $\mathcal{E}$ Development, vol. 20, no. 7, pp. 759-771. http://dx.doi.org/10.1101/gad.1410506. PMid:16600909.

WANG, L., ZHAO, H., CHEN, D., LI, L., SUN, H., LOU, Y. and GAO, Z., 2016. Characterization and primary functional analysis of a bamboo NAC gene targeted by miR164b. Plant Cell Reports, vol. 35, no. 6, pp. 1371-1383. http://dx.doi.org/10.1007/s00299016-1970-6. PMid:27021381.

WANG, Y., SHEN, D., BO, S., CHEN, H., ZHENG, J., ZHU, Q., CAI, D., HELLIWELL, C. and FAN, L., 2010. Sequence variation and selection of small RNAs in domesticated rice. BMC Evolutionary Biology, vol. 10, no. 1, pp. 119. http://dx.doi.org/10.1186/14712148-10-119. PMid:20429951.

WEI, L., ZHANG, D., XIANG, F. and ZHANG, Z., 2009. Differentially expressed miRNAs potentially involved in the regulation of defense mechanism to drought stress in maize seedlings. International Journal of Plant Sciences, vol. 170, no. 8, pp. 979989. http://dx.doi.org/10.1086/605122.

WU, B., LI, W., XU, H., QI, L. and HAN, S., 2015. Role of cin-miR2118 in drought stress responses in Caragana intermedia and tobacco. Gene, vol. 574, no. 1, pp. 34-40. http://dx.doi.org/10.1016/j. gene.2015.07.072. PMid:26216304.

XIA, K., WANG, R., OU, X., FANG, Z., TIAN, C., DUAN, J., WANG, Y. and ZHANG, M., 2012. OsTIR1 and OsAFB2 downregulation via OsmiR393 overexpression leads to more tillers, early flowering and less tolerance to salt and drought in rice. PLoS One, vol. 7, no. 1, pp. e30039. http://dx.doi.org/10.1371/journal. pone.0030039. PMid:22253868.

XIAO, L., QUAN, M., DU, Q., CHEN, J., XIE, J. and ZHANG, D., 2017. Allelic interactions among Pto-MIR475b and its four target genes potentially affect growth and wood properties in Populus. Frontiers in Plant Science, vol. 8, pp. 1055. http://dx.doi. org/10.3389/fpls.2017.01055. PMid:28680433.

XIONG, L., WANG, R.-G., MAO, G. and KOCZAN, J.M., 2006. Identification of drought tolerance determinants by genetic analysis of root response to drought stress and abscisic acid. Plant Physiology, vol. 142, no. 3, pp. 1065-1074. http://dx.doi. org/10.1104/pp.106.084632. PMid:16963523.

YAN, J., ZHAO, C., ZHOU, J., YANG, Y., WANG, P., ZHU, X., TANG, G., BRESSAN, R.A. and ZHU, J.-K., 2016. The miR165/166 Mediated Regulatory Module Plays Critical Roles in ABA Homeostasis and Response in Arabidopsis thaliana. PLOS Genetics, vol. 12, no. 11, pp. e1006416. http://dx.doi.org/10.1371/journal.pgen.1006416. PMid:27812104.

YANG, C., LI, D., MAO, D., LIU, X., JI, C., LI, X., ZHAO, X., CHENG, Z., CHEN, C. and ZHU, L., 2013. Overexpression of microRNA319 impacts leaf morphogenesis and leads to enhanced cold tolerance in rice (Oryza sativa L.). Plant, Cell E'Environment, vol. 36, no. 12, pp. 2207-2218. http://dx.doi.org/10.1111/pce.12130. PMid:23651319.

ZHANG, X., ZOU, Z., GONG, P., ZHANG, J., ZIAF, K., LI, H., XIAO, F. and YE, Z., 2011. Over-expression of microRNA169 confers enhanced drought tolerance to tomato. Biotechnology Letters, vol. 33, no. 2, pp. 403-409. http://dx.doi.org/10.1007/s10529-010-0436-0. PMid:20960221.

ZHOU, L., LIU, Y., LIU, Z., KONG, D., DUAN, M. and LUO, L., 2010. Genome-wide identification and analysis of drought-responsive microRNAs in Oryza sativa. Journal of Experimental Botany, vol. 61, no. 15, pp. 4157-4168. http://dx.doi.org/10.1093/jxb/ erq237. PMid:20729483.

ZHOU, M., LI, D., LI, Z., HU, Q., YANG, C., ZHU, L. and LUO, H., 2013. Constitutive expression of a miR319 gene alters plant development and enhances salt and drought tolerance in transgenic creeping bentgrass. Plant Physiology, vol. 161, no. 3, pp. 1375-1391. http://dx.doi.org/10.1104/pp.112.208702. PMid:23292790.

ZHU, J., 2002. Salt and drought stress signal transduction in plants. Annual Review of Plant Biology, vol. 53, no. 1, pp. 247-273. http://dx.doi.org/10.1146/annurev.arplant.53.091401.143329. PMid:12221975. 